\title{
Lead and Cadmium Removal from Aqueous Medium Using Coir Pith as Adsorbent: Batch and Fixed bed Column Studies
}

\author{
B.M.W.P.K. Amarasinghe \\ Department of Chemical and Process Engineering, University of Moratuwa, Sri Lanka.
}

Date Received: 31-03-2011 Date Accepted: 02-09-2011

\begin{abstract}
Coir pith was used as an alternative to commonly available adsorbents for heavy metal ion removal from aqueous solutions. Batch and fixed bed column experiments were conducted to study adsorption characteristics of $\mathrm{Cd}$ and $\mathrm{Pb}$ onto coir pith. Coir pith is an effective adsorbent for $\mathrm{Pb}$ and $\mathrm{Cd}$ removal. The adsorbent dose, metal ion concentration and the solution $\mathrm{pH}$ affects the degree of adsorption. The maximum adsorption was observed at solution $\mathrm{pH}$ values above 5 . The equilibrium data was satisfactorily fitted to Langmuir and Freundlich isotherms. $\mathrm{Pb}$ showed higher adsorption capacity compared to $\mathrm{Cd}$ under the experimental conditions. Kinetic studies revealed that $\mathrm{Pb}$ and $\mathrm{Cd}$ uptake was fast within first 10 to $15 \mathrm{~min}$ of contact time and data fits to pseudo second-order model. Breakthrough curve data fits to linear Bed Depth Service Time (BDST) model and bed capacities for Pb and Cd were 41 and $28 \mathrm{mg} /$ $\mathrm{g}$ of coir pith respectively.
\end{abstract}

Key words: adsorption, heavy metals, coir pith

Correspondence: E-mail padma@cheng.mrt.ac.lk,

$\mathrm{Tel}+94112640474$

ISSN 2235-9370 Print/ ISSN 2235-9362 Online @2011 University of Sri Jayewardenepura 


\section{Introduction}

Heavy metals are continuously released into water sources from natural and industrial processes. Some heavy metals such as cadmium and lead are highly toxic as ions and/or in neutral forms. Among the number of waste treatment processes available, the adsorption is widely used especially for solutions at low metal concentrations (Corbitt, 1999). However, commercially available adsorbents are expensive and hence there is a significant need for development of alternative adsorbents that are low cost and effective.

Investigations have been conducted to test various plant materials as low-cost adsorbents for heavy metal ion removal. Studies have shown that materials can be treated physically, chemically or thermally to enhance adsorption properties (Babu and Ramakrishna, 2003). Rice husk (Chuah et.al., 2005, Amarasinghe et al., 2005), tea waste (Amarasinghe and Williams, 2007, Malkoc and Nutoglu, 2005, 2006), saw dust (Sciban, 2006, Shukla, 2002,2005), tree leaves and barks (Baig, 1999, Palma et al., 2003) and coconut husk based products (Santhy and Selvapathy, 2006, Namasivayan and Sangeetha, 2006, Macedo et al., 2006 Shukla et al., 2006, Conrad and Hansen, 2007) have all been tested for their adsorption characteristics for dyes, heavy metals and other organic matter.

This work investigates the potential of raw coir pith for $\mathrm{Cd}$ and $\mathrm{Pb}$ removal from aqueous solutions. Batch adsorption tests were conducted to determine equilibrium characteristics, kinetic data and factors affecting adsorption. In industry, fixed-bed columns are widely used for adsorption and, hence, fixed bed column tests were conducted to investigate the practical applicability. Breakthrough curves were obtained and adsorption characteristics in column operations were determined.

\section{Materials and methods}

\subsection{Preparation of the adsorbent}

Coir pith was obtained from the coconut-coir pith bricks imported to USA from Sri Lanka (The Lazy Gardener, Whittier, California). Soluble and coloured components were removed from coir pith by washing with water. The process was repeated until the water was virtually colourless. The coir pith was then washed with distilled water and oven dried for $12 \mathrm{hrs}$ at $85^{\circ} \mathrm{C}$. The dried coir pith was sieved $(350 " 850 \mu \mathrm{m})$ and stored in sealed polythene bags until use.

\subsection{Synthetic waste water preparation}

Synthetic wastewater solutions were prepared by dissolving analytical grade $\mathrm{Cd}\left(\mathrm{NO}_{3}\right)_{2} \cdot 3 \mathrm{H}_{2} \mathrm{O}$ and $\mathrm{Pb}\left(\mathrm{NO}_{3}\right)$ in distilled water to obtain $1000 \mathrm{mg}$ of metal per $\mathrm{L}$ of solution. The stock solutions were diluted to the required concentration for experiments. The $\mathrm{pH}$ of the solution was measured and observed as $5.5 \pm 0.5$, and no chemicals were added to change $\mathrm{pH}$ except for the $\mathrm{pH}$ experiments.

\subsection{Batch adsorption tests}

Batch adsorption tests were conducted by mixing known weight of coir pith and solution of known metal-ion concentration (in the range $50 " 150 \mathrm{mg} / \mathrm{L}$ ). The mixture was shaken in a mechanical shaker and $5 \mathrm{~mL}$ samples of solution were withdrawn from the bottle at known time intervals. The sample was 
filtered to remove any fine particles and analyzed for the metal ion. A series of experiments were conducted to determine the effect of adsorbent dose, initial metal ion concentration, equilibrium isotherms and effect of solution $\mathrm{pH}$. The solution $\mathrm{pH}$ was at $5.5 \pm 0.5$ (except for effect of $\mathrm{pH}$ experiments) and all the experiments were conducted at room temperature at $26 \pm 2{ }^{\circ} \mathrm{C}$.

\subsection{Fixed bed experiments}

Fixed bed column adsorption experiments were conducted in a small $1.5 \mathrm{~cm}$ diameter glass column. The column was filled with a known weight of coir pith to obtain the required bed height. The metal ion solution containing $100 \mathrm{mg} / \mathrm{L}$ of $\mathrm{Cd}$ or Pb was fed to the column at a constant flow rate of $5.5 \mathrm{~mL} / \mathrm{min}$ through the bed using a peristaltic pump. The solution leaving the bottom of the column was collected at various time intervals and the samples were analyzed.

The batch and column adsorption experiments were performed in duplicate to observe the reproducibility.

\subsection{Metal analysis and adsorbent characterization}

Atomic absorption spectrophotometer (Perkin Elmer-Model 3110) with an air-acetylene flame and hollow cathode lamps for $\mathrm{Cd}$ and $\mathrm{Pb}$ was used for metal ion analysis. The absorbance of the samples was read in triplicate. The surface area of coir pith was measured using BET surface area analyzer (Quantachrome). The size of the coir pith was determined by sieve analysis. True and bulk densities of coir pith were also determined using the specific gravity bottle method. Scanning electron microscope photographs were obtained for coir pith using Field emission SEM S4700 (Hitachi corporation).

\section{Results and Discussion}

\subsection{Properties of CoirPith}

Physical properties of coir pith determined as described above are listed in Table 1. The textural structure examination of coir pith particles can be observed from the SEM photographs in Figure 1(a). The pore size distribution is shown in Figure. 1 (b).

\subsection{Effect of adsorbent dose}

The effect of adsorbent dose on percentage removal of $\mathrm{Pb}$ and $\mathrm{Cd}$ ions is shown in Figures 2(a) and (b) for a $\mathrm{pH}$ of 5.5. The percentage of lead ion removal increased from $31 \%$ to $98 \%$ when the adsorbent dose was increased from $0.5^{\prime \prime} 10.0 \mathrm{~g} / \mathrm{L}$. Cd adsorption was lower compared to $\mathrm{Pb}$, and the minimum dose of coir pith required for $98 \% \mathrm{Cd}$ removal was $10.0 \mathrm{mg} / \mathrm{L}$ solution. The number of adsorption sites and specific surface area increases with the weight of adsorbent, and, hence, results in a higher percent of metal removal at high dose. However, as shown in the Figure. 2(b) amount of metal ions adsorbed per unit weight of adsorbent $(q)$ decreases with the adsorbent dose. This shows that at higher dose the adsorbent is not fully utilized. 


\subsection{Effect of initial metal ion concentration}

Figures. 3(a) and (b) show the percentage of ions removed as a function of time for a range of $\mathrm{Pb}$ and $\mathrm{Cd}$ ion concentrations for a $\mathrm{pH}$ of 5.The $\mathrm{Pb}$ and $\mathrm{Cd}$ ion removal percentages increased as the initial ion concentration decreased. At low ion concentrations, the ratio of surface active sites to total metal ions in the solution was high, and, hence, all metal ions may have interacted with the adsorbent and have been removed from the solution. However, the amount of metal adsorbed per unit weight of adsorbent, $q$, is higher at high concentrations. The values were 17, 23 and 25 for $\mathrm{Cd}$ and 20,38 and $52 \mathrm{mg} / \mathrm{g}$ for Pb at 50 , 100 and $150 \mathrm{mg} / \mathrm{L}$ initial concentrations respectively.

\begin{tabular}{lc}
\hline \multicolumn{1}{c}{ Property } \\
\hline Mean Particle size $(\mathrm{mm})$ & 513 \\
Surface area $\left(\mathrm{m}^{2} / \mathrm{g}\right)$ & 1.56 \\
Pore size $\left(\mathrm{A}^{\circ}\right)$ & 45.2 \\
Bulk density $\left(\mathrm{kg} / \mathrm{m}^{3}\right)$ & 116 \\
True density $\left(\mathrm{kg} / \mathrm{m}^{3}\right)$ & 799 \\
\hline
\end{tabular}

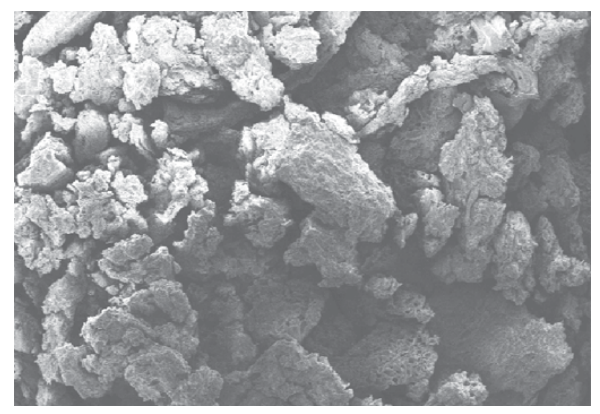

Figure 1 (a) : Electron microscopy (SEM) of coir pith.

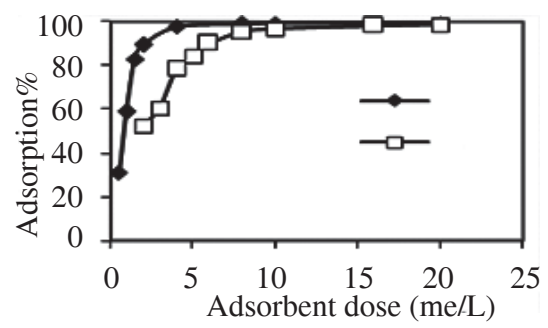

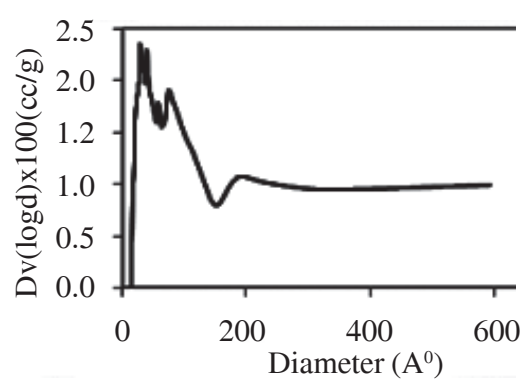

Figure 1(b):Pore size distribution of coir pith.

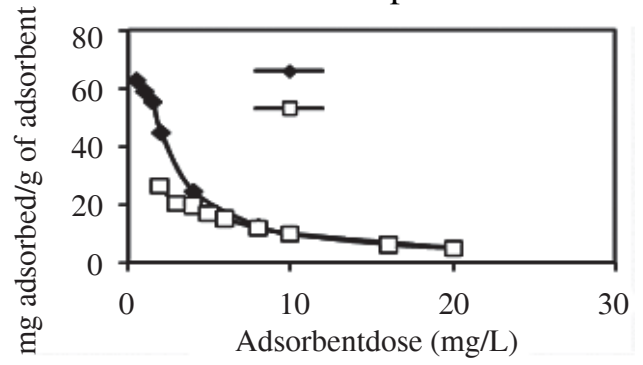

Figure 2: Effect of adsorbent dose on $\mathrm{Cd}$ and $\mathrm{Pb}$ adsorption onto coirpith from $100 \mathrm{mg} / \mathrm{L}$ solution at $26^{\circ} \mathrm{C}$. 

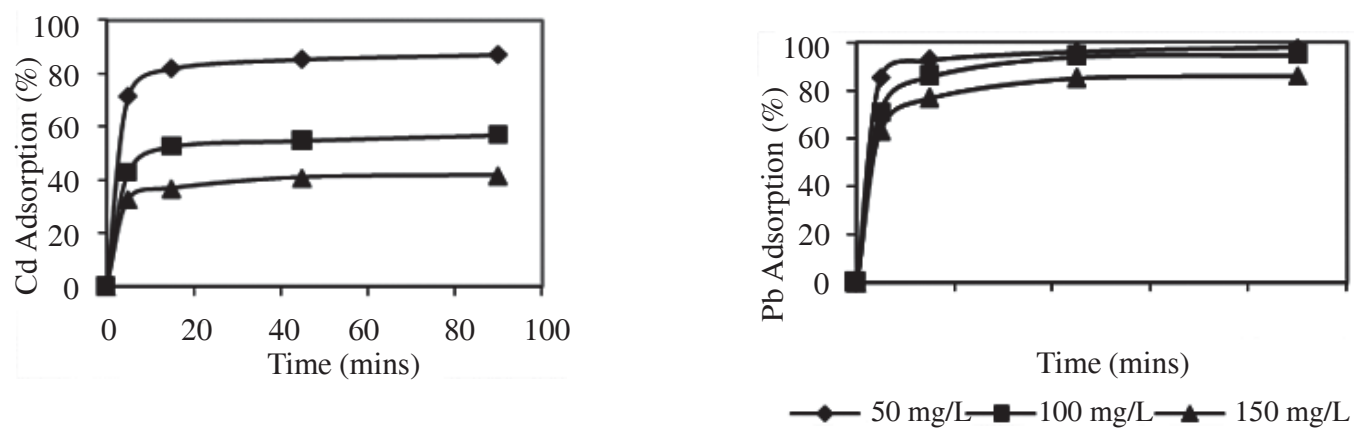

Figure 3: Effect of initial solution concentration on adsorption of $\mathrm{Cd}(\mathrm{a})$ and $\mathrm{Pb}(\mathrm{b})$ onto coir pith, dose $2.5 \mathrm{~g} / \mathrm{L}, 26^{\circ} \mathrm{C}$.

\subsection{Adsorption Isotherms}

Several equilibrium models have been developed to describe adsorption isotherm relationships (Seader, 2006). The Langmuir model was originally developed for adsorption of gases onto solids, and is based on the assumption that adsorption occurs on localized sites with no interaction between adsorbate molecules and maximum adsorption occurs when the surface is covered by a monolayer of adsorbate. For solid-liquid systems, the linear form of the isotherm can be expressed by the equation (1):

$$
q_{e}=\frac{q_{o} b C_{e}}{\left(1+b C_{e}\right)}
$$

.The Freundlich isotherm model is an empirical model for adsorption, and is expressed as;

$$
q_{e}=k C_{e}^{1 / n}
$$

Where $\mathrm{b}=$ adsorption coefficient $(\mathrm{L} / \mathrm{mg})$.

$\mathrm{C}_{\mathrm{e}}=$ the residual liquid phase concentration at equilibrium (mg/L).

$\mathrm{k}=$ constants related to adsorption capacity

$\mathrm{n}=$ constants related to adsorption intensity

$\mathrm{q}_{\mathrm{e}}=$ the amount of metal adsorbed per unit weight of adsorbent $(\mathrm{mg} / \mathrm{g})$ at equilibrium

$\mathrm{q}_{\mathrm{o}}=$ the amount of solute adsorbed per unit weight of adsorbent corresponding to complete coverage of available sites $(\mathrm{mg} / \mathrm{g})$.

The experimental data were fitted to both Langmuir and Freundlich isotherms using linear regression of the linearized forms of Eq. 1 and 2. The isotherm coefficients in equations (1) and (2), and the regression coefficients $\left(\mathrm{R}^{2}\right)$, are given in Table 2 . The $1 / \mathrm{n}$ values for both $\mathrm{Pb}$ and $\mathrm{Cd}$ lie between zero and 1, thereby, indicating a favorable adsorption isotherm. Overall, $\mathrm{Pb}$ had a higher adsorption capacity as compared to $\mathrm{Cd}$. 
Table 2: Langmuir and Freundlich isotherm data for adsorption of $\mathrm{Pb}$ and $\mathrm{Cd}$ onto coir pith at $26^{\circ} \mathrm{C}$.

\begin{tabular}{ccccccc}
\hline Metal & \multicolumn{3}{l}{ Freundlich Constants } & \multicolumn{4}{c}{ Langmuir Constants } \\
\cline { 2 - 7 } & \multicolumn{1}{c}{$\mathrm{k}$} & $1 / \mathrm{n}$ & $\mathrm{R}^{2}$ & $\mathrm{q}_{\mathrm{o}}$ & $\mathrm{b}$ & $\mathrm{R}^{2}$ \\
\hline $\mathrm{Cd}$ & 4.91 & 0.4372 & 0.9161 & 25.83 & 0.1510 & 0.9866 \\
$\mathrm{~Pb}$ & 15.03 & 0.3845 & 0.8943 & 71.90 & 0.1774 & 0.9842 \\
\hline
\end{tabular}

The results discussed, so far, indicate a higher adsorption of $\mathrm{Pb}$ compared to $\mathrm{Cd}$ for the experimental conditions under observation. This may be explained by the hydration enthalpy which is the energy that permits the detachment of $\mathrm{H}_{2} \mathrm{O}$ molecules from cations, and then reflects the easiness for the ion to interact with the functional groups on coir pith particles. The more a cation is hydrated, the stronger its hydration enthalpy, and the less it could interact with the adsorbent. Hydration enthalpies of $\mathrm{Pb}$ and $\mathrm{Cd}$ are -1481 and $-1807 \mathrm{~kJ} / \mathrm{kg}$, respectively (www.science.uwaterloo.ca) which indicates a theoretical high affinity of $\mathrm{Pb}$ cations to the adsorbent and, hence, higher removal of $\mathrm{Pb}$ compared to $\mathrm{Cd}$. $\mathrm{Pb}$ has shown higher adsoption capacities than several other heavy metal types such as $\mathrm{Cu}, \mathrm{Cd}, \mathrm{Ni}, \mathrm{Zn}$ (Amarasinghe, 2007, Martin-Dupoint, 2002, Ricordal, 2001).

\subsection{Effect of solution $\mathrm{pH}$}

Figure 4 shows the percentage of metal ions adsorbed on to coir pith as a function $\mathrm{pH}$. $\mathrm{Cd}$ and $\mathrm{Pb}$ adsorption show maximum removal in the $\mathrm{pH}$ range 5-7. At $\mathrm{pH}$ 2-3 range the adsorption is very low, and rapidly increases between $\mathrm{pH} 4-5$. This phenomenon can be explained by the weakly acidic nature of surface functional groups of the coir pith. At low $\mathrm{pH}$, acidic surface functional groups tend to be protonated, and, hence, do not significantly participate in ion exchange reaction due to strong competition of protons for those sites. These data are in agreement with the results obtained for other biomass materials such as coffee residues (Boonamnuayvitaya, 2004), orange waste (Dhakal, 2005), coca shells (Meunier, 2003), sago waste (Quek, 1998) and saw dust (Sciban, 2006, Shukla, 2002) by other workers.

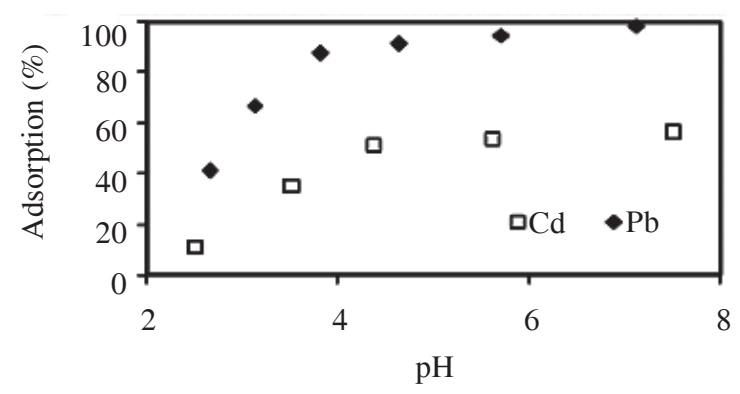

Figure 4: Effect of $\mathrm{pH}$ on adsorption of $\mathrm{Cd}$ and $\mathrm{Pb}$ onto coir pith, dose $2.5 \mathrm{~g} / \mathrm{L}, 26^{\circ} \mathrm{C}$.

At very high $\mathrm{pH}$ values (e.g., $\mathrm{pH}$ of 7), metal complex forms and results in the precipitation of metal salts, and, therefore, the metal removal may be due to this other mechanism in addition to adsorptive ion 
exchange (Aslam, 2004, Gaikwad, 2004, Sciban, 2006). Hence, adsorption of $\mathrm{Cd}$ and $\mathrm{Pb}$ cations onto coir pith could be at optimum in the $\mathrm{pH}$ range 5-6.

\subsection{Adsorption kinetics}

Adsorption kinetics controls the solute uptake rate which, in turn, controls the length of the mass transfer zone within a contactor, and (indirectly) affects the size of the adsorption equipment. Our experimental results in Figures 3(a) and (b) for coir pith show rapid initial adsorption rate followed by a slower rate. It is hypothesized that these results are due to the porous structure of the coir pith. Specifically, larger open pores would be rapidly accessible with little diffusional constraints. However, there appears to be a fraction of exchange sites in surface regions with much smaller pores for which slow diffusion plays an important role. The results suggest that most of the exchange sites (e.g., 90\%) appear to be accessible in the fast diffusion kinetic region, and that the slowly accessible sites are relatively minimal.

Several adsorption kinetic models have been developed, and widely used, to describe adsorption kinetics (Ho, 1999, Onganer, 1998, Preetha, 2005, Qadeer, 2005, Uzun, 2000, Horsfall, 2003). The Lagregran pseudo-first-order model can be expressed as:

$$
\begin{aligned}
& \frac{d q}{d t}=k_{1}\left(q_{e}-q\right) \\
& \ln \left(q_{e}-q\right)=\ln \left(q_{e}\right)-k_{1} t
\end{aligned}
$$

where $\mathrm{q}$ is the capacity at time $(\mathrm{t}), \mathrm{q}_{\mathrm{e}}$ is the equilibrium capacity, and $\mathrm{k}_{1}$ is the pseudo-first-order adsorptive rate constant.

Alternatively, the second-order model is expressed as:

$$
\begin{aligned}
& \frac{d q}{d t}=k_{2}\left(q_{e}-q\right)^{2} \\
& \frac{t}{q}=\frac{t}{q_{e}}+\frac{1}{k_{2} q_{e}^{2}}
\end{aligned}
$$

where $\mathrm{k}_{2}$ is the second-order rate constant. The initial adsorption rate $(h)$ is equal to $k_{1} q_{e}$ and $k_{2} q_{e}^{2}$ $\left(\mathrm{mg} \mathrm{g}^{-1} \mathrm{~min}^{-1}\right.$ ) for first- and second-order models, respectively.

These models were used to analyze the nature of the adsorption kinetics for $\mathrm{Cd}$ and $\mathrm{Pb}$ on coconut coir pith. Specifically, the results obtained for adsorption of $\mathrm{Cd}$ and $\mathrm{Pb}$ onto coir pith as function time were fitted to both Eq. 4 (pseudo-first order) and Eq. 6 (second order). The results showed that the second-order model, given by Eq. 6. provides better correlation than pseudo-first-order model. The corresponding second-order kinetic parameters, and correlation coefficients, thus obtained are shown in Table.3. Experimentally determined sorption capacities shown in the last column of the table are in 
agreement with the equilibrium sorption capacities $q$, determined using second order model. $\mathrm{Pb}$ shows higher initial adsorption rate $(h)$ compared to $\mathrm{Cd}$ for all concentrations. However, rate constant $k$, for $\mathrm{Cd}$ is higher than $\mathrm{Pb}$ except for $50 \mathrm{mg} / \mathrm{L}$ concentration.

Table 3: Second order kinetic parameters for adsorption of $\mathrm{Pb}$ and $\mathrm{Cd}$ onto coir pith.

\begin{tabular}{lllllll}
\hline Metal & $\begin{array}{l}\text { Solution } \\
\text { conc. } \\
(\mathrm{mg} / \mathrm{l})\end{array}$ & $\begin{array}{l}h\left(\mathrm{mg} \mathrm{g}^{-1}\right. \\
\left.\mathrm{min}^{-1}\right)\end{array}$ & $\begin{array}{l}k_{2}\left(\mathrm{~g} \mathrm{mg}^{-1}\right. \\
\left.\mathrm{min}^{-1}\right)\end{array}$ & $q_{\text {pre }}(\mathrm{mg} / \mathrm{g})$ & $\mathrm{R}^{2}$ & $\begin{array}{l}-q_{\text {exp }} \\
(\mathrm{mg} / \mathrm{g})\end{array}$ \\
\hline $\mathrm{Cd}$ & 150 & 13.64 & 0.0288 & 25.57 & 0.9999 & 25.08 \\
& 100 & 12.78 & 0.0238 & 23.15 & 0.9990 & 22.74 \\
& 50 & 14.34 & 0.0462 & 17.60 & 1 & 17.39 \\
$\mathrm{~Pb}$ & 150 & 26.52 & 0.0093 & 53.19 & 1 & 51.82 \\
& 100 & 22.17 & 0.0147 & 38.75 & 0.9999 & 37.99 \\
& 50 & 20.24 & 0.0514 & 19.84 & 1 & 19.64 \\
\hline
\end{tabular}

\subsection{Fixed bed adsorption}

Breakthrough curves obtained from fixed-bed column operations for $\mathrm{Pb}$ and $\mathrm{Cd}$ adsorption onto coir pith from single metal ion solutions at $100 \mathrm{mg} / \mathrm{L}$ are shown in Figure 5. Typical ' $S$ ' shaped curves breakthough curves were obtained for all experiments. The area above the breakthrough curve is a measure of the bed capacity $(B C)$. The average bed capacities for $\mathrm{Cd}$ and $\mathrm{Pb}$ were 18 and $54 \mathrm{mg} / \mathrm{g}$, respectively. These results suggest that raw coir pith can be used as low cost adsorbent for removal of $\mathrm{Cd}$ and $\mathrm{Pb}$ from waste water. The above values can be compared with the model predictions based on batch experiments. For Cd, model values predicted by the Langmuir and Freundlich models are 24 and $36, \mathrm{mg} / \mathrm{g}$, respectively (for $100 \mathrm{mg} / \mathrm{L}$ aqueous equilibrium concentration). For $\mathrm{Pb}$, model values predicted by the Langmuir and Freundlich models are 68 and 88, mg/g, respectively (for $100 \mathrm{mg} / \mathrm{L}$ aqueous equilibrium concentration). Bed capacities obtained by column experiments are lower than model predictions which can be due to following reasons. In batch experiments the mixture was shaken continuously and good interaction between the solid and solute was achieved. In the fixed bed, adsorbent is packed in the column and surface of the solid particles are in contact with each other and therefore results a less solid-solute interaction. Further, liquid channeling which results in poor solid-metal ion contact and less residence time may occur in the column. Therefore bed adsorption capacities are lower compared to batch operation.

The Bed Depth Service Time (BDST) is a simple model for the prediction of adsorber performance (Lee, 2000).The model proposes a relationship between bed depth, Z, and the time taken for breakthrough to occur, and assumes that the adsorption rate is proportional to both the residual adsorbent capacity and the remaining adsorbate concentration. The linearised equation can be expressed as follows: 


$$
t=\frac{N o}{C o V} Z-\frac{1}{K C o} \ln \left(\frac{C o}{C b}-1\right)
$$

Where $C o, C b=$ initial and breakthrough metal ion concentrations (mg/L).

$K=$ Adsorption rate constant $(\mathrm{L} / \mathrm{mg} \mathrm{min})$.

No $\quad=$ adsorptive capacity $(\mathrm{mg} / \mathrm{L})$.

$t=$ service time $(\min )$.

$V \quad=$ linear flow rate of $\operatorname{solution}(\mathrm{m} / \mathrm{min})$

$Z \quad=\operatorname{bed}$ height $(\mathrm{m})$.

The bed depth verses service time plots for $\mathrm{Cd}$ and $\mathrm{Pb}$ adsorption onto coir pith are shown in Figure 7. Breakthrough was assumed at $10 \%$ of the feed concentration. The results show that the bed depth service time were linear indicating the validity of BDST model for this system.

Bed capacity $\left(N_{0}\right)$ and the adsorption rate constant $(K)$ were calculated from the gradient and the intercept of the BDST plots. The computed $N_{o}$ and $K$ values were $4921 \mathrm{mg} / \mathrm{L}(41 \mathrm{mg} / \mathrm{g})$ and $0.00345 \mathrm{~L} /$ $\mathrm{mg}$ min for $\mathrm{Pb}$ and $2782 \mathrm{mg} / \mathrm{L}(23 \mathrm{mg} / \mathrm{g}$ ) and $0.000919 \mathrm{~L} / \mathrm{mg} \mathrm{min}$ for $\mathrm{Cd}$, respectively. The bed capacities thus calculated are in agreement with the batch experimental results, and the values obtained from the breakthrough curve areas. Jusoh et al.(2007) have tested adsorption of $\mathrm{Pb}$ and $\mathrm{Cd}$ onto granular activated carbon (size 850-100 mm for initial solution concentrations of $20 \mathrm{mg} / \mathrm{L}$ ), which typically has a surface area around $500-600 \mathrm{~m}^{2} / \mathrm{g}$ and obtained $N_{0}$ and $K$ values of $2308 \mathrm{mg} / \mathrm{L}$ and $0.00013 \mathrm{~L} / \mathrm{mg} \mathrm{min}$ for $\mathrm{Pb}$ and $1552 \mathrm{mg} / \mathrm{L}$ and $0.00023 \mathrm{~L} / \mathrm{mg}$ min for Cd respectively. $N_{o}$ and $K$ values obtained in this work are also in the same order of magnitude as the results obtained for Ni adsorption onto tea waste (Malkoc, 2006). These BDST model parameters can be useful in designing industrial adsorption units.
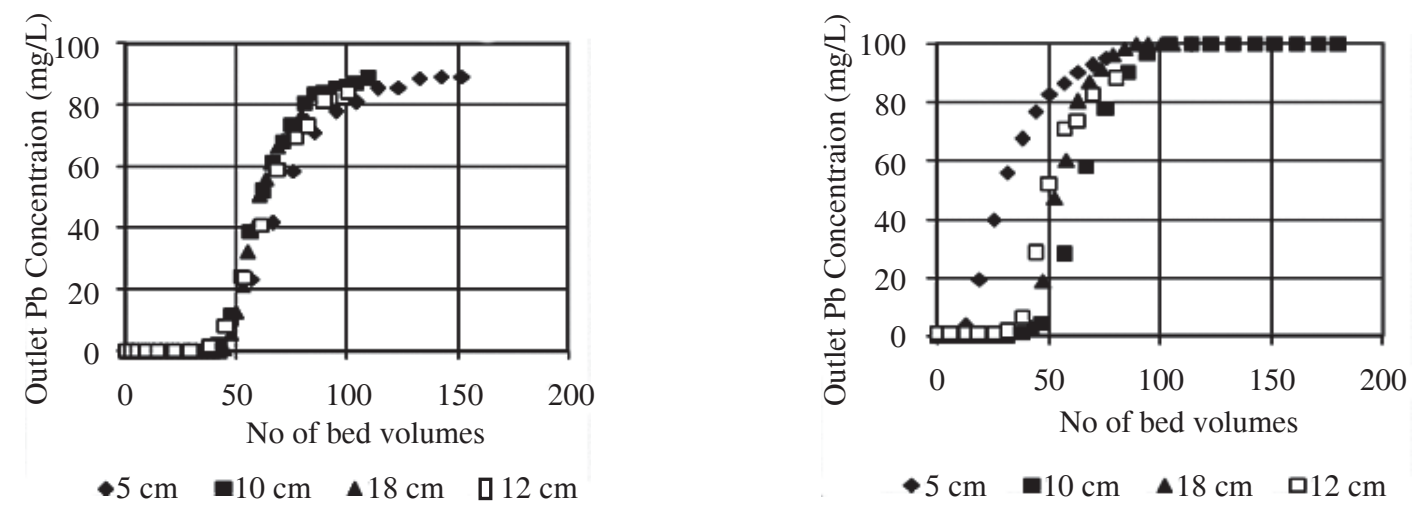

Figure 5: Breakthrough curves for adsorption of $\mathrm{Pb}$ and $\mathrm{Cd}$ onto coir pith at various bed heights, $5.5 \mathrm{ml} . / \mathrm{min}$ 


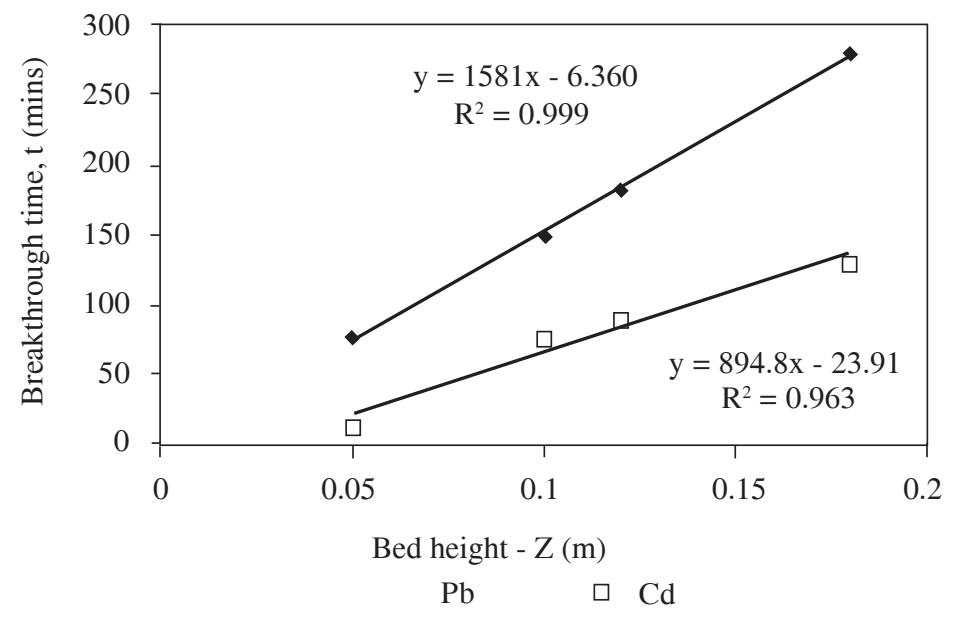

Fig 7: BDST plots for $\mathrm{Cd}$ and $\mathrm{Pb}\left(\mathrm{eq}^{\mathrm{n}} 7\right)$

The adsorption capacities achieved for a specific situation will depend on the operating conditions, the source of coir pith, the pretreatments given, and other factors. Coir pith used for this work was not treated chemically or thermally. Chemical or thermal treatments of adsorbents could be used to enhance the adsorptive properties of coir pith. However, these treatments are costly, add complexity to the process, and could add other chemicals to water. However, the results of the present work show raw coir pith has a good adsorption capacity for $\mathrm{Pb}$ and $\mathrm{Cd}$, and may be suitable as an alternative to higher cost adsorbents.

\section{Conclusions}

Results showed that coir pith is an effective and inexpensive adsorbent for cadmium and lead from aqueous solutions. The adsorption capacity strongly depends on the solution to adsorbent ratio used and the solution $\mathrm{pH}$. Adsorption was maximum at solution $\mathrm{pH}$ values above 5. Adsorption is fast with $90 \%$ of the adsorption occurring within the first $10 \mathrm{~min}$. Kinetic data fits to the second-order model. The equilibrium isotherms can be represented by both the Freundlich and Langmuir models. Pb showed higher adsorption capacity and affinity compared to $\mathrm{Cd}$ under all the experimental conditions studied. Fixed-bed column results show that data fits to the linear BDST model. Computed Bed capacity (No) and the BDST adsorption rate constant $(K)$ were $4921 \mathrm{mg} / \mathrm{L}$ and $0.00345 \mathrm{~L} / \mathrm{mg}$ min for $\mathrm{Pb}$ and $2782 \mathrm{mg} /$ $\mathrm{L}$ and $0.000919 \mathrm{~L} / \mathrm{mg}$ min for Cd respectively.

\section{Acknowledgements}

Author wishes to thank Sri Lanka-United States Fulbright commission for providing fellowship. The support from Professors J. Raper, C. Adams and D. Ludlow enabling to conduct experiments at University of Missouri-Rolla, USA is greatly acknowledged. 


\section{References}

Amarasinghe B.M.W.P.K., Gangodavilage N., 2005, Adsorbents from waste biomass: Production and Application, $7^{\text {th }}$ World Congress of Chemical Eng., Glasgow, July.10-14.

Amarasinghe B.M.W.P.K. and Williams R.A., 2007, Tea waste as an adsorbent for $\mathrm{Cu}$ and $\mathrm{Pb}$ removal from wastewater, Chem. Eng. J., 132 (2007) 299-309.

Aslam, M.M., Hassen I., Malik, M. and Martin, A., 2004, Removal of copper from industrial effluent by adsorption with economically viable material, EJEAFChe,3 (2),ISSN 1579-4377.

Babu, B.V. and Ramakrishnan, V., 2003, Ranking of adsorbents based on method of preparation and Isotherm Fitting, Proceedings of international symposium \& $56^{\text {th }}$ Annual session of IIChE, (CHEMCON), Bhubaneswar, December 19-22.

Baig, T.H., Garcia, A.E., Tiemann, K.J., and Gardea-Torresdey, J.L., 1999, Adsorption of heavy metal ions by the biomass of solanum elaeagnifolium (silver leaf night-shade), Proceedings of the hazardous waste research conference, St Louis, Missouri, May 24-27, 131-142.

Boonamnuayvitaya, V., Chaiya, C., Tanthapanichakoon, W. and Jarudilikkul, S., 2004, Removal of heavy metals by adsorbent prepared from pyrolyzed coffee residues and clay, Separation and purification Technology, 35, 11-22.

Chuah T.G., Jumasiah, A., Azni I., Katayon S., Thomas Choong, S.Y., 2005, Rice husk as a potentially low-cost biosorbent for heavy metal and dye removal: an overview, Desalination, 175, 305-316.

Conrad, K, and Hansen, H, C., B., 2007, Sorption of zinc and lead on coir, Bioresource Technol., 98(1), 89-97.

Corbitt R.A., Standard Hand Book of Environmental Engineering, $2^{\text {nd }}$ edition, McGrawHill, 1999.

Dhakal, R. P., Ghimire, K.N., and Inoue, K., 2005, Adsorptive separation of heavy metal from an aquatic environment using orange waste, hydromettalurgy, 79, 182-190.

Gaikwad, R.W., 2004, Removal of CD(ii) fom aqueous solution by activated charcoal derived from coconul shell, EJEAF.

Ho, Y.S., and McKay, G., 1999, Pseudo-second order model for sorption processes, Process Biochemistry, 34, 451-465.

Horsfall, M. and A. A. Abia, Sorption of cadmium(II) and zinc(II) ions from aqueous solutions by cassava waste biomass (Manihot sculenta Cranz), Water Research, Volume 37, Issue 20 , December 2003, Pages 4913-4923.

Jusoh, A., Shiung, L.S., Ali, N. and Noor, M.J.M.M., 2007, A simulation study of the removal efficiency of granular activated carbon on cadmium and lead, Desalination, 206, 9-16.

Lee V.K.C., Porter J.F. and McKay, G., 2000, Developemnt of fixed bed adsorber correlation models, Ind. Eng.,Chem. Res., 39(7), 2427-2433.

Macedo J.D,S., Costa N., Almeida, L, Vieira E., Cestari A., Gimenez I., Carreno, N. and Barreto L., 2006, Kinetic and calorimetraic study of the adsorption of dyes on mesoporous activated carbon prepared from coconut coir dust, J. of Colloid and Interface Sci., 298, 515-522.

Malkoc E. and Nutoglu, Y., 2006, Removal of Ni(II) ions from aqueous solutions using waste of tea factory: Adsorption on a fixed -bed column, J. of hazardous materials, B135, 328-336.

Malkoc, E. and Nutoglu, Y., 2005, Investigation of nickel II removal from aqueous solution using factory waste, J. of hazardous materials, B127, 120-128. 
Martin-Dupoint F. et.al., 2002, Heavy metal adsorption by crude coniferous barks: A modelling study, J. Environ. Sci. Health, A37(6), 1063-1073.

Meunier, N. et.al., 2003, Lead removal from acidic solutions by sorption on coca shells: Effect of some parmeters, J. of Env. Eng. @ ASCE, August, 693-698.

Namsivayam, C. and Sangeetha, D., 2006, Recycling of agricultural waste, coir pith : Removal of anions, heavy metals, organics and dyes from water by adsorption onto $\mathrm{ZnCl}_{2}$ activated coir pith carbon., J. of hazardous materials, B135, 449-452.

Onganer, Y. and Temur, C., 1998, Adsorption dynamics of Fe(III) from aqueous solutions onto activated carbon, J. of colloid \& Interface Science, 205, 241-244.

Palma G., Freer, J. and Baeza, J., 2003, Removal of metal ions by modified Pinus radiata bark and tannins from water solutions, Water Research , 37,20, 4974-4980.

Preetha, B. and Viruthagiri, T., 2005, Biosorption of zinc(ii) by rhizopus arrhizus: equilibrium and kinetic modelling, African J. of biotechnology, 4(6), 506-508.

Qadeer, R and Akhtar, S., 2005, Kinetics study of lead ion adsorption on active carbon, Turk J. Chem, 29, 95-99.

Quek, S.Y., Wase, D.A.J. and Forster, C.F., 1998, The use of sago waste for the sorption of lead and copper, Water SA, 24(3), 251-256.

Ricordel, S. et. al., 2001, Heavy metals removal by adsorption onto peanut husks carbon: Characterization, kinetic study and modelling, separation and purification technology, 24, 389-401.

Santhy K. and Selvapathy P., 2006, Removal of reactive dyes from wastewater by adsorption on coir pith activated carbon, Bioresource Technol., 97, 1329-1336.

Sciban, M. and Klasnja, 2004, Wood sawdust and wood originate materials as adsorbents for heavy metal ions, European J. of wood and wood products, 62 (1),69-73.

Seader, J.D. and Henly, E.J., 2006, Separation process priniples, 2nd edition, John Wiley and Sons, Inc.USA.

Shukla A., Zhange Y., Dubey P., Margrave J.L. and Shukla S.S., 2002, The role of saw dust in the removal of unwanted materials from water, J. of Hazardous Materials, B95, 137-152.

Shukla S.R. and Pai R.S., 2005, Comparison of $\mathrm{Pb}(\mathrm{II})$ uptake by coir and dye loaded coir fibres in a fixed bed column, B125, 147-153.

Shukla, S.R., Pai R.S., and Shendarkar A.D., 2006, Adsorption of Ni(II), Zn(II) and Fe(II) on modified coir fibers, Separation and purification technology, 47(3), 141-147.

Uzun, I. and Guzel, F., 2000, Adsorption of some heavy metal ions from aqueous solution by activated carbon and comparison of percent adsorption results of activated carbon with those of some other adsorbents, Turk J. Chem., 24, 291-297. 